\title{
Parental stress in raising children with special needs $(\mathrm{CWSN})$
}

\section{Sushmita Borah and Sampreety Gogoi}

Received: 19.10.2019; Revised: 04.03.2020; Accepted: 18.04.2020

See end of the paper for authors' affiliations

\section{Sushmita Borah}

Department of Human

Development and Family

Studies, College of Community

Science, Assam Agricultural

University, Jorhat (Assam) India

Email : sushmitaborah@gmail.

com
ABSTRACT : Parenting stress is an experience of every parent in the parenting process. It is experienced by almost all parents in raising their children, but it is more increased in parents having children with special needs (CWSN). The birth of a child with special needs often bring changes in the life of the parents for which they might not be prepared and will have bigger challenges to overcome in future. So, the present study entitled "Parental stress in raising children with special needs (CWSN)" was conducted in Jorhat district of Assam so as to assess the level of stress in parents raising children with special needs. A sample of 80 parents was selected purposively from special schools of Jorhat. Findings of the present study revealed that majority of the parents had an average level of stress in raising their children with special needs.

KEY WORDS: Parental stress, Children with special needs, Level of stress

-HOW TO CITE THIS PAPER : Borah, Sushmita and Gogoi, Sampreety (2020). Parental stress in raising children with special needs (CWSN). Asian J. Home Sci., 15 (1) : 12-16, DOI: 10.15740/HAS/AJHS/15.1/ 12-16. Copyright@ 2020: Hind Agri-Horticultural Society. 